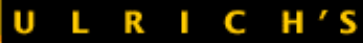
Periodicals Directory"

The globalsourcefor

periodicals information since-1932
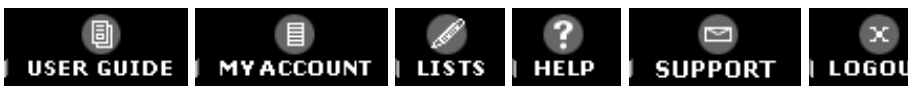

Advanced Search Browse Ulrich's Alert Ulrich's Update

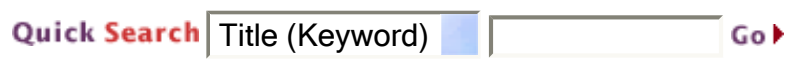

\title{
Parasitology (Cambridge)
}

¿ BACK TO RESULTS

SEARCH MY LI BRARY'S CATALOG: ISSN Search | Title Search

\begin{tabular}{|c|c|c|c|c|c|}
\hline $\begin{array}{c}\text { Basic } \\
\text { Description }\end{array}$ & \multicolumn{2}{|c|}{$\begin{array}{l}\text { Other Editions/ } \\
\text { Formats }\end{array}$} & $\begin{array}{c}\text { Abstracting / } \\
\text { Indexing } \& \text { Article } \\
\text { Access }\end{array}$ & $\begin{array}{c}\text { Publisher \& } \\
\text { Ordering } \\
\text { Information }\end{array}$ & $\begin{array}{c}\text { Advertising, Rights, } \\
\text { Demographics }\end{array}$ \\
\hline \multicolumn{6}{|c|}{ G S F F X } \\
\hline \multicolumn{6}{|c|}{ Click highlighted text for a new search on that item. } \\
\hline \multicolumn{2}{|c|}{ Table of Contents: } & \multicolumn{2}{|c|}{$\underline{\text { Click here to view }}$} & & \\
\hline \multicolumn{2}{|c|}{ ISSN: } & \multicolumn{2}{|c|}{$0031-1820$} & & \\
\hline \multicolumn{2}{|l|}{ Title: } & \multicolumn{3}{|c|}{ Parasitology (Cambridge) } & $\nabla$ Additional Title Information \\
\hline \multicolumn{2}{|c|}{ Publishing Body: } & \multicolumn{3}{|c|}{ Cambridge University Press } & \\
\hline \multicolumn{2}{|c|}{ Country: } & \multicolumn{3}{|c|}{ United Kingdom } & \\
\hline \multicolumn{2}{|l|}{ Status: } & \multicolumn{3}{|c|}{ Active } & \\
\hline \multicolumn{2}{|l|}{ Start Year: } & \multicolumn{3}{|c|}{1908} & \\
\hline \multicolumn{2}{|c|}{ Frequency: } & \multicolumn{3}{|c|}{ Monthly (Plus two supplements) } & \\
\hline \multicolumn{2}{|c|}{ Document Type: } & \multicolumn{3}{|c|}{ J ournal; Academic/Scholarly } & \\
\hline \multicolumn{2}{|c|}{ Refereed: } & \multicolumn{3}{|c|}{ Yes } & \\
\hline \multicolumn{2}{|c|}{ Abstracted/ I ndexed: } & \multicolumn{3}{|l|}{ Yes } & \\
\hline \multicolumn{2}{|c|}{ Media: } & \multicolumn{3}{|c|}{ Print } & \\
\hline \multicolumn{2}{|c|}{$\begin{array}{l}\text { Alternate Edition } \\
\text { ISSN: }\end{array}$} & \multicolumn{3}{|c|}{$\underline{1469-8161}$} & \\
\hline \multicolumn{2}{|c|}{ RSS Availability: } & \multicolumn{4}{|c|}{ Click here to view } \\
\hline \multicolumn{2}{|l|}{ Language: } & Text & in English & & \\
\hline Price: & & $\begin{array}{l}\text { GBP } \\
\text { GBP } \\
\text { (Prin } \\
\text { (effe }\end{array}$ & $\begin{array}{l}945, \text { USD } 1,810 \\
990, \text { USD } 1,880 \\
\text { \& Online Eds.) } \\
\text { tive 2009) }\end{array}$ & $\begin{array}{l}\text { scription pe } \\
\text { nbined subs }\end{array}$ & $\begin{array}{l}\text { year to institutions } \\
\text { ription per year to institutions }\end{array}$ \\
\hline Subject: & & MED & CAL SCIENCES - & MMUNICA & E DISEASES \\
\hline Dewey \#: & & 616. & & & \\
\hline LC\#: & & QL7: & & & \\
\hline CODEN: & & PAR & & & \\
\hline Special Fea & es: & Inclu & des Advertising, & ok Reviews & \\
\hline Article I nde & & Inde & & & \\
\hline Editor(s): & & $\mathrm{CAr}$ & ee, R.S. Phillips & & \\
\hline URL: & & $\underline{\mathrm{http}}$ & /journals.cambri & e.org/actior & displayl ournal?jid=PAR \\
\hline Description & & $\begin{array}{l}\text { Pub } \\
\text { inclu } \\
\text { topi }\end{array}$ & $\begin{array}{l}\text { hes papers on a } \\
\text { ing biochemical, } \\
\text {, with emphasis }\end{array}$ & $\begin{array}{l}\text { spects of } p \\
\text { imunologic } \\
\text { parasites }\end{array}$ & $\begin{array}{l}\text { e and applied parasitology, } \\
\text { physiological, and ecological } \\
\text { d their control. }\end{array}$ \\
\hline
\end{tabular}

\section{ADDI TI ONAL TITLE I NFORMATI ON}

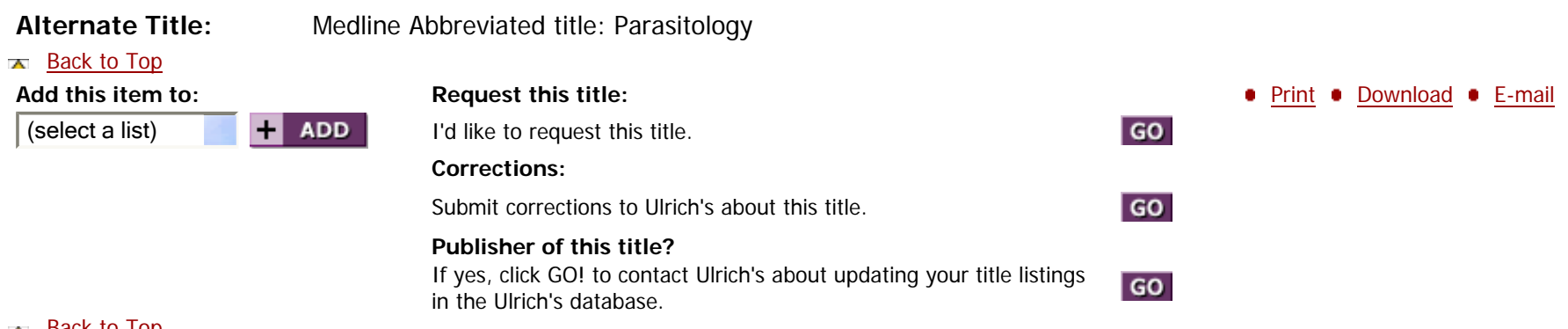




\title{
Glycosidase activity in the excretory-secretory products of the liver fluke, Fasciola hepatica
}

\author{
J. A. IRWIN ${ }^{1 *}$, P. E. W. MORRISSEY ${ }^{1}$, J. P. RYAN ${ }^{1}$, A. WALSHE 2 , S. M. O’NEILL ${ }^{2}$, \\ S. D. CARRINGTON ${ }^{3}$, E. MATTHEWS ${ }^{3}$, E. FITZPATRICK ${ }^{3}$, G. MULCAHY ${ }^{4}$, \\ A. P. CORFIELD ${ }^{5}$ and J. P. DALTON ${ }^{2} \uparrow$ \\ ${ }^{1}$ Department of Veterinary Physiology and Biochemistry, Faculty of Veterinary Medicine, University College Dublin, Belfield, \\ Dublin 4, Ireland \\ ${ }^{2}$ School of Biological Sciences, Dublin City University, Glasnevin, Dublin 9, Ireland \\ ${ }^{3}$ Department of Veterinary Anatomy, Faculty of Veterinary Medicine, University College Dublin, Belfield, Dublin 4, Ireland \\ ${ }^{4}$ Department of Veterinary Microbiology and Parasitology, Faculty of Veterinary Medicine, University College Dublin, \\ Belfield, Dublin 4, Ireland \\ ${ }^{5}$ Mucin Research Group, Division of Medicine, Fenner Yard, Bristol Royal Infirmary, Marlborough Street, \\ Bristol BS2 $8 H W, U K$
}

(Received 16 February 2004; revised 12 March 2004; accepted 12 March 2004)

SUMMARY

Fasciola hepatica secretes proteolytic enzymes and other molecules that are essential for host penetration and migration. This mixture may include enzymes required for the degradation of supramucosal gels, which defend epithelial surfaces against pathogen entry. These contain hydrated mucins that are heavily glycosylated. Excretory-secretory products (ES) from $F$. hepatica were examined for a range of glycosidase activities, using synthetic 4-methylumbelliferyl glycosides as substrates. The ES product contained at least 8 different glycosidase activities, the most abundant of which were $\beta$-N-acetylhexosaminidase, $\beta$-galactosidase and $\beta$-glucosidase. Alpha-fucosidase, $\beta$-glucuronidase, $\alpha$-galactosidase, $\alpha$ mannosidase and neuraminidase were also present. $\beta$-N-acetylhexosaminidase and $\beta$-galactosidase were present in multiple isoforms (at least 4 ), whereas $\beta$-glucosidase appeared to exist as one isoenzyme with a $\mathrm{pI}<3 \cdot 8$. All three enzymes had acidic $\mathrm{pH}$ optima $(4 \cdot 5-5 \cdot 0)$. Ovine small intestinal mucin was degraded by $\mathrm{ES}$ at $\mathrm{pH} 4 \cdot 5$ or $7 \cdot 0$, with or without active cathepsin L, the major protease found in $F$. hepatica ES. The ability of $F$. hepatica ES to degrade mucin in the presence or absence of active cathepsin $\mathrm{L}$ suggests that cathepsin $\mathrm{L}$ is not essential for mucin degradation. The abundance of $\beta$-galactosidase and $\beta$-hexosaminidase in ES supports a role for these enzymes in mucin degradation.

Key words: mucin, $\beta$-galactosidase, $\beta$-N-acetylhexosaminidase, $\beta$-glucosidase.

\section{INTRODUCTION}

Fasciola hepatica, or liver fluke, is a trematode helminth parasite that is widespread in the world's temperate regions and causes fasciolosis, a chronic liver disease. This disease is commonly encountered in ruminants, causing billions of dollars in agricultural losses each year. In addition, it is also a cause of debilitating human disease, particularly in the developing world, where it affects $2 \cdot 4$ million people (Mas-Coma, Bargues \& Esteban, 1999). In common with many parasitic organisms, it secretes excretorysecretory (ES) products that are critical in enabling the parasite to invade and digest its way into host tissue and directly defend itself against host immune

* Corresponding author: Department of Veterinary Physiology and Biochemistry, Faculty of Veterinary Medicine, University College Dublin, Belfield, Dublin 4, Ireland. Tel: +3531716 6216. Fax: +3531716 6219 . E-mail: jane.irwin@ucd.ie

$\dagger$ Present address: Institute for the Biotechnology of Infectious Diseases (IBID), University of Technology, Sydney, Westbourne Street, Gore Hill, Sydney, NSW 2065, Australia. attack (Smith et al. 1993). Cathepsin L cysteine proteases are the most abundant enzymes in Fasciola ES and facilitate host invasion as well as nutrient acquisition. In addition, they degrade host antibody (Smith et al. 1993), preventing antibody-mediated eosinophil attachment to newly excysted juveniles (Carmona et al. 1993), and suppress Th1 immune responses in vivo (O'Neill, Mills \& Dalton, 2001). These products are of considerable interest as potential vaccine candidates (Dalton et al. 1996; Mulcahy et al. 1998). A preliminary proteomic study of $F$. hepatica ES has also demonstrated the presence of a wide range of other proteins, including various anti-oxidant enzymes (Jefferies et al. 2001).

Fasciola hepatica is likely to require glycosidases for the degradation of host glycans, facilitating penetration of host tissue, and digestion of proteoglycans or glycoproteins in host blood cells or tissues as a source of nutrition. Glycosidases have been studied extensively from mammalian, plant, fungal and bacterial sources, but little is known about trematode glycosidases. Some histological studies have localized glycosidase activity in flukes. Moore \& Halton (1976) showed that $\beta$-hexosaminidase was present in the 
tegument of 4-week-old juvenile flukes, with a lower abundance in the parenchyma. These activities declined at the adult stage. Fujino \& Ishii (1986) found strong $\beta$-galactosidase activity in the brush border of the caeca in $F$. hepatica. Some $\beta$-hexosaminidase activity was also demonstrated in parenchymal cells. No $\beta$-glucuronidase activity was detected in adult flukes in either study. However, to date no studies have been performed to assess the glycosidase content of $F$. hepatica ES.

The present study examines the glycosidase activity in $F$. hepatica ES. Three enzymes, $\beta$-hexosaminidase, $\beta$-galactosidase and $\beta$-glucosidase were found to be the most abundant glycosidases present. These enzymes were partially purified and characterized with respect to their physiochemical and kinetic properties. In addition, the mucin-degrading capability of $F$. hepatica $\mathrm{ES}$ was investigated in the presence and absence of active cathepsin L.

\section{MATERIALS AND METHODS}

Adult $F$. hepatica were obtained from the bile ducts of infected cattle slaughtered in a local abattoir, washed in warm PBS and then incubated in Roswell Park Memorial Institute (RPMI) medium containing $1 \%$ glucose (40 worms per $200 \mathrm{ml}$ medium). After $6 \mathrm{~h}$ the medium was removed and centrifuged at $14000 \boldsymbol{g}$ for $30 \mathrm{~min}$. The supernatant was concentrated to $20 \mathrm{ml}$ (protein concentration $0 \cdot 15-4 \cdot 0 \mathrm{mg} / \mathrm{ml}$ ) using an Amicon ultrafiltration unit and a membrane molecular size cut-off at $10 \mathrm{kDa}$. 4-Methylumbelliferyl glycosides, glycosidase inhibitors, Q-Sepharose, Sephacryl S300-HR, butylSepharose, PBE 94 chromatofocusing gel, Polybuffer 74, guanidinium chloride, SigmaMarker wide range molecular weight standards for SDS-PAGE, ZPhe-Ala diazomethylketone and other chemicals were obtained from Sigma-Aldrich Chemical Co., Tallaght, Dublin 24, Ireland. The Bio-Rad protein assay reagent was obtained from Bio-Rad Laboratories. Recombinant cathepsin L1 was purified from Pichia pastoris as described by Collins et al. (2004).

\section{Glycosidase assay}

A 96-well plate fluorescent assay, based on the glycosidase assays of Corfield \& Myerscough (2000) was employed. A sample of $\operatorname{ES}(10 \mu l)$ was added to a buffer solution (generally $0 \cdot 1 \mathrm{M}$ sodium citrate, $\mathrm{pH} 4$-5) containing a 4-methylumbelliferyl (4-MU) glycoside $(40 \mu \mathrm{l})$, giving a final substrate concentration of $0.5 \mathrm{~mm}$. $\beta$-galactosidase, $\beta$-N-acetylhexosaminidase, $\beta$-glucosidase, $\alpha$-galactosidase, $\alpha$ fucosidase, $\alpha$-mannosidase, $\beta$-glucuronidase and sialidase were assayed using the following 4-methylumbelliferyl glycosides: 4-MU- $\beta$-D-galactoside, 4MU-N-acetyl- $\beta$-D-glucosaminide, 4-MU-N-acetyl$\beta$-D-galactosaminide, 4-MU- $\beta$-D-glucoside, 4-MU-
$\alpha$-D-galactoside, 4-MU- $\alpha$-L-fucoside, $\quad 4-\mathrm{MU}-\alpha$ D-mannopyranoside, 4-MU- $\beta$-D-glucuronide hydrate and 2 - $-(4-\mathrm{MU})-\alpha-\mathrm{D}-\mathrm{N}$-acetylneuraminic acid sodium dihydrate.

The plates were covered in aluminium foil to prevent evaporation and maintain the contents in darkness, and incubated at $37^{\circ} \mathrm{C}$ for $2 \mathrm{~h}$. The reaction was then stopped by the addition of $200 \mu \mathrm{l} 0.25 \mathrm{M}$ glycine/ $\mathrm{NaOH}, \mathrm{pH} 10 \cdot 5$. This enhances the fluorescence of the product 4-methylumbelliferone, which does not fluoresce in neutral or acidic solution. The fluorescence of the sample was read in a fluorescent plate reader (Molecular Devices: Spectra max Gemini), excitation wavelength $365 \mathrm{~nm}$, emission $460 \mathrm{~nm}$. The product concentration was calculated by reference to a standard curve $(0-80 \mu \mathrm{M})$ of 4 methylumbelliferone.

Kinetic parameters were estimated using nonlinear regression by the method of Wilkinson (1961). Rate data $(10-500 \mu \mathrm{m}$ for $\beta$-galactosidase and $\beta$ hexosaminidase, $50 \mu \mathrm{M}-2 \mathrm{~mm}$ for $\beta$-glucosidase) were fitted with the program Enzpack 3.0 (Biosoft, Cambridge, UK).

\section{Glycosidase purification}

$F$. hepatica ES was subjected to anion-exchange chromatography on $1 \mathrm{ml}$ columns of Q-Sepharose equilibrated with $25 \mathrm{~mm}$ sodium phosphate buffer, $\mathrm{pH} 8 \cdot 0$, and eluted stepwise with $0 \cdot 1,0 \cdot 25,0 \cdot 5$ and $1 \cdot 0 \mathrm{M} \mathrm{NaCl}$ in the same buffer. A sample of ES was also subjected to hydrophobic chromatography on butyl-Sepharose equilibrated with $0 \cdot 1 \mathrm{M}$ sodium phosphate buffer, $\mathrm{pH} 7 \cdot 0$, containing $4 \mathrm{~m} \mathrm{NaCl}$ and enzyme activity was eluted stepwise using buffer containing salt concentrations from $2 \cdot 5-0 \mathrm{M} \mathrm{NaCl}$. The sample was also concentrated to approximately $500 \mu \mathrm{l}$ using Centricon 10 centrifugal microconcentrators and chromatographed on a Sephacryl $\mathrm{S}-300$ column, $1 \times 47 \mathrm{~cm}$, equilibrated in $50 \mathrm{~mm}$ sodium phosphate buffer, $\mathrm{pH} 7 \cdot 0$.

Chromatofocusing was carried out using $1 \mathrm{ml}$ aliquots of $\mathrm{ES}$ on a $1 \mathrm{ml}$ column of PBE 94, equilibrated with 20 volumes of $25 \mathrm{~mm}$ imidazole/ $\mathrm{HCl}$ buffer, pH 7·4. A gradient was generated using $16 \mathrm{ml}$ of Polybuffer 74 , adjusted to $\mathrm{pH} 4 \cdot 0$, to give a $\mathrm{pH}$ gradient from $7 \cdot 0$ to $4 \cdot 0$. This was used to resolve glycosidase isoforms. The purity of the fractions from each chromatographic step was analysed by SDS-PAGE using a Mini-Protean III apparatus (Bio-Rad) on 10\% SDS-polyacrylamide gels (Laemmli, 1970).

\section{Protein assay}

Protein concentration was determined by the BioRad assay method (Bradford, 1976) using bovine serum albumin as standard. Protein elution patterns from columns were monitored using the absorbance at $280 \mathrm{~nm}$. 


\section{Mucin purification}

Mucins were extracted from the mucous secretions of sheep duodenum and jejunum as described by Davies \& Carlstedt (2000). The solubilized mucin preparation was adjusted from $6 \mathrm{M}$ to $4 \mathrm{M}$ guanidinum chloride by the addition of phosphate buffered saline, $\mathrm{pH} 7 \cdot 4$. CsCl was added until the buoyant density of the solution was $1.4 \mathrm{~g} / \mathrm{ml}$. The solution was centrifuged at $70000 \boldsymbol{g}$ in a Beckman Optima LE80-K ultracentrifuge using a $70.1 \mathrm{Ti}$ rotor for $18 \mathrm{~h}$ at $10^{\circ} \mathrm{C}$ to establish an isopycnic density gradient. The centrifuge tubes were removed carefully to avoid perturbing the gradient $(1 \cdot 2-1 \cdot 6 \mathrm{~g} / \mathrm{l})$ and $1 \mathrm{ml}$ aliquots were removed sequentially from the top of the tube. These were slot blotted under vacuum onto polyvinylidene difluoride (PVDF) membranes and stained with periodic acid/Schiff (PAS) stain (Thornton et al. 1989) to detect the carbohydrate portion of mucin. Fractions containing mucin were pooled and chromatographed on a Sepharose CL2B column $(2 \cdot 5 \times 91 \mathrm{~cm})$ equilibrated with $50 \mathrm{~mm}$ Tris/100 mM $\mathrm{KCl}$ buffer, pH 7·5. Fractions $(4 \mathrm{ml})$ were collected and analysed as described above for carbohydrate content. Mucincontaining fractions eluted in the void volume, and were lyophilized and dissolved in approx. $20 \mathrm{ml}$ of distilled, deionized water. The mucin was then desalted on a Sephadex G-25 column equilibrated with distilled deionized water, lyophilized, and stored at $-20{ }^{\circ} \mathrm{C}$.

\section{Determination of molecular weight}

The molecular weights of the glycosidases were determined by gel filtration on a Sephacryl S300 HR column $(1 \times 45 \mathrm{~cm})$ relative to those of molecular weight standards (carbonic anhydrase, $29 \mathrm{kDa}$; bovine serum albumin, $66 \cdot 2 \mathrm{kDa}$; yeast alcohol dehydrogenase, $150 \mathrm{kDa} ; \beta$-amylase, $200 \mathrm{kDa}$; apoferritin, $443 \mathrm{kDa})$. A sample of $\operatorname{ES}(600 \mu \mathrm{l})$ was chromatographed and the enzyme activities were detected in the fractions eluted as described above.

\section{Assessment of the extent of mucin degradation}

The degradation of mucin by ES components was assessed by incubating $0.4 \mathrm{mg}$ of ovine duodenal or jejunal mucin with $F$. hepatica $\mathrm{ES}(50 \mu \mathrm{l})$ in different buffers in a total volume of $1 \mathrm{ml}$ for $24 \mathrm{~h}$ at $37^{\circ} \mathrm{C}$. Purified $F$. hepatica cathepsin L1 was added to some incubations. The samples were then chromatographed on a Sepharose CL2B column $(1 \times 45 \mathrm{~cm})$ equilibrated with $50 \mathrm{~mm}$ sodium phosphate, $\mathrm{pH} 7 \cdot 0$, and $1 \mathrm{ml}$ fractions were collected. Aliquots of the fractions $(20-50 \mu \mathrm{l})$ were slot blotted under vacuum onto PVDF membranes as described above and stained using PAS. The intensity of the staining was estimated by densitometric scanning.
Table 1. Glycosidase activity in Fasciola hepatica ES

(Three different batches of Fasciola hepatica ES were assayed with the appropriate 4-methylumbelliferyl glycosides as described in Materials and Methods. $\beta$-Nacetylhexosaminidase was assayed using 4-MU N-acetylglucosaminide as substrate. (The protein concentrations of the three batches were batch $1,0.14 \mathrm{mg} / \mathrm{ml}$; batch 2 , $0 \cdot 43 \mathrm{mg} / \mathrm{ml}$; batch $3,1 \cdot 86 \mathrm{mg} / \mathrm{ml}$.))

\begin{tabular}{lccl}
\hline \hline & Activity $(\mathrm{nmol} / \mathrm{h} / \mathrm{mg}$ protein $)$ \\
\cline { 2 - 4 } Glycosidase & Batch 1 & Batch 2 & Batch 3 \\
\hline$\alpha$-L-fucosidase & $17 \cdot 3$ & $80 \cdot 4$ & - \\
$\beta$-D-galactosidase & 1375 & 363 & $53 \cdot 8$ \\
$\alpha$-D-galactosidase & $45 \cdot 4$ & $56 \cdot 7$ & - \\
$\beta$-D-acetylhexosaminidase & $91 \cdot 7$ & 347 & $86 \cdot 2$ \\
$\beta$-D-glucosidase & $40 \cdot 3$ & 309 & $53 \cdot 8$ \\
$\beta$-glucuronidase & $24 \cdot 3$ & $69 \cdot 8$ & - \\
$\alpha$-mannosidase & $27 \cdot 4$ & $81 \cdot 6$ & $14 \cdot 3$ \\
$\alpha$-neuraminidase & $15 \cdot 0$ & $4 \cdot 3$ & - \\
\hline \hline
\end{tabular}

\section{Activity staining of $\mathrm{F}$. hepatica tissue}

Adult $F$. hepatica were obtained from freshly slaughtered cattle at a local abattoir. The flukes were mounted in Tissue-Tek OCT embedding compound (Ames Laboratories) and sectioned at $5 \mu \mathrm{m}$ thickness on a cryomicrotome. The sections were maintained at $-20{ }^{\circ} \mathrm{C}$ prior to staining for $\beta$-galactosidase, $\beta$ $\mathrm{N}$-acetylhexosaminidase, and $\beta$-glucosidase activity using a modification of the method of Lojda (1970) as described by Everson Pearse (1972). The stain contained the following components: $6 \mathrm{mg} 5$-bromo4-chloro-3-indolyl- $\beta$-D-galactopyranoside (X-Gal) or the corresponding glucopyranoside or N-acetylglucosaminide (X-Glc, X-GlcNac) dissolved in $0.6 \mathrm{ml} \mathrm{N}, \mathrm{N}$-dimethylformamide; $14 \mathrm{ml} 0.1 \mathrm{M}$ citratephosphate buffer, $\mathrm{pH} 4.5 ; 1.0 \mathrm{ml} 50 \mathrm{~mm}$ potassium ferricyanide; $1.0 \mathrm{ml} 50 \mathrm{~mm}$ potassium ferrocyanide. The samples were incubated overnight $(18-20 \mathrm{~h})$ at $37^{\circ} \mathrm{C}$. Glycosidase activity was indicated by the presence of a deep blue-green stain.

RESULTS

\section{Enzyme activities}

The glycosidase activities in three batches of $F$. hepatica ES were determined (Table 1). In all cases, $\beta$-galactosidase, $\beta$-N-acetylhexosaminidase, and $\beta$ glucosidase were the most abundant activities, whereas the activity of $\alpha$-L-fucosidase and neuraminidase was consistently low. However, the relative abundance of these enzymes varied from batch to batch. For example, batch 1 contained relatively little $\beta$-glucosidase, and a high level of $\beta$-N-acetylhexosaminidase. Batch 3 contained low levels of all the enzymes assayed. The variations in levels of these enzymes may be related to the differences in the maturity of the flukes obtained. All the flukes used 
for ES production were adult, but their relative ages are unknown, since the host animals were infected naturally, rather than experimentally. Intestinal mucin glycans are frequently capped with $\alpha-1,2$ linked fucose and sialic acid, so these enzymes would be essential for assisting in the degradation of mucin in a sequential manner from the capping sugars towards the protein core. However, mucins are rich in galactose, $\mathrm{N}$-acetylglucosamine and $\mathrm{N}$-acetylgalactosamine, and the high levels of $\beta$-galactosidase and $\beta$-N-acetylhexosaminidase would be consistent with a role for these in mucin degradation.

\section{Glycosidase isoforms}

Initially, attempts were made to purify the enzymes by anion-exchange chromatography on Q Sepharose. Chromatography in $25 \mathrm{~mm}$ sodium phosphate buffer, pH 8.0, showed that the enzymes eluted at different ionic strengths. About $50 \%$ of the $\beta$-galactosidase failed to bind to the column, eluting instead when the column was washed stepwise with 100 and $250 \mathrm{~mm} \mathrm{NaCl}$, whereas $65 \%$ of the $\beta$-N-acetylhexosaminidase activity eluted at $250 \mathrm{~mm} \mathrm{NaCl}$ and $25 \%$ of the activity was eluted in the wash fractions. The $\beta$-glucosidase activity was almost entirely eluted from the column by $100 \mathrm{~mm} \mathrm{NaCl}$. This heterogeneous elution profile hinted strongly at the presence of multiple isoforms. This was confirmed by butyl-Sepharose hydrophobic chromatography and chromatofocusing. $\beta$-Galactosidase was eluted in a single peak from a butyl-Sepharose column when it was eluted with $1.5 \mathrm{M} \mathrm{NaCl}$, whereas $\beta$-N-acetylhexosaminidase eluted in a series of peaks when the column was eluted sequentially with $2 \mathrm{M}, 1.75 \mathrm{M}$, $1 \cdot 5 \mathrm{M}, 1 \mathrm{M} \mathrm{NaCl}$ and finally with buffer containing no salt. $\beta$-Glucosidase was eluted in a single peak by $1.5 \mathrm{M} \mathrm{NaCl}$.

Chromatofocusing confirmed the presence of at least 3 and possibly $4-5$ isoforms of $\beta$ - N-acetylhexosaminidase (Fig. 1A). Three isoforms predominated with $\mathrm{pI}$ values of $>7 \cdot 0,4 \cdot 7$ and $<3 \cdot 8$, with minor isoforms at $\mathrm{pI} 6 \cdot 0$ and $4 \cdot 4$. $\beta$-Galactosidase also had at least 4 isoforms, with $\mathrm{pI}$ values of $>7 \cdot 0,5 \cdot 9,4 \cdot 5$ and $<3.8$ (Fig. 1B) and a minor isoform of pI 4.8 was apparent in some preparations. The ratios of these peaks, and hence isoforms, varied from batch to batch. $\beta$-Glucosidase eluted as a single peak at a $\mathrm{pI}$ value $<3 \cdot 8$ (Fig. 1C). This suggests that this enzyme exists as just one single, highly acidic isoform, although other isoforms with lower $\mathrm{pI}$ values may be present.

The molecular weights were determined by gel filtration on a Sephacryl S300 HR column. The values obtained were $110 \pm 5 \mathrm{kDa}$ for $\beta$-N-acetylhexosaminidase, $37 \pm 5 \mathrm{kDa}$ for $\beta$-galactosidase and $44 \pm 5 \mathrm{kDa}$ for $\beta$-glucosidase. The elution profiles of the $\beta$-galactosidase and $\beta$-glucosidase activities were different, implying that they were unlikely to be on the same protein.
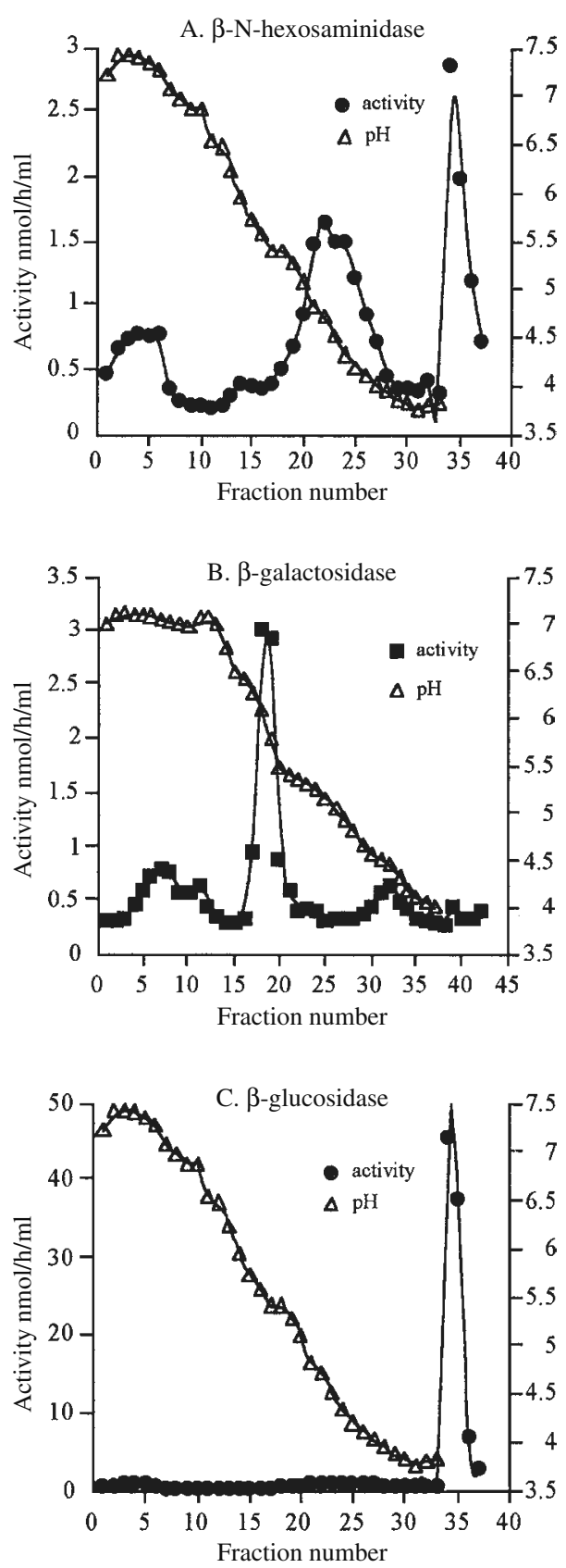

Fig. 1. Elution profiles of Fasciola hepatica glycosidases from a PBE 94 chromatofocusing column. Samples of $F$. hepatica ES were prepared and chromatographed as described in Materials and Methods. Fractions $(600 \mu \mathrm{l})$ were collected and assayed for the appropriate enzyme. At the end of each $\mathrm{pH}$ gradient (pH 3.8 approx.) the column was eluted with $1 \mathrm{M} \mathrm{NaCl}$ in Polybuffer 74 to elute any remaining proteins with $\mathrm{pI}$ values $<3 \cdot 8$. These proteins eluted in fractions $34-37$. Figures $\mathrm{A}, \mathrm{B}$, and $\mathrm{C}$ show the elution profiles for $\beta$-N-acetylhexosaminidase, $\beta$-galactosidase and $\beta$-glucosidase, respectively.

A partial purification of the enzymes was accomplished, but full purification was hindered by the scarcity of material and by the diversity of isoenzymes present. These glycosidases constituted only a very small proportion of the proteins 
Table 2. Properties of Fasciola hepatica glycosidases

(The apparent $\mathrm{K}_{\mathrm{m}}$ values for the $\beta$-N-acetylhexosaminidase isoforms were measured after separation by ion-exchange chromatography on Q Sepharose. Isoform 1 of $\beta$ - $\mathrm{N}$-acetylhexosaminidase did not bind to $\mathrm{Q}$ Sepharose at $\mathrm{pH} 8 \cdot 0$ : isoforms 2 and 3 were eluted by $100 \mathrm{~mm} \mathrm{NaCl}$ and $250 \mathrm{~mm} \mathrm{NaCl}$, respectively. (Values are stated \pm standard deviation for 4 determinations.))

\begin{tabular}{llll}
\hline \hline & \multicolumn{2}{l}{ Enzyme } & \\
\cline { 2 - 4 } Property & $\beta$-hexosaminidase & $\beta$-galactosidase & $\beta$-glucosidase \\
\hline No. of isoforms & $\geqslant 4$ & $\geqslant 4$ & 1 \\
$\mathrm{M}_{r}(\mathrm{kDa})$ (gel filtration) & $110 \pm 5$ & $37 \pm 5$ & $44 \pm 5$ \\
pH optimum & $4 \cdot 5-5 \cdot 0$ & $4 \cdot 5-5 \cdot 0$ & $4 \cdot 5-4 \cdot 8$ \\
4-MU substrate $\mathrm{K}_{\mathrm{m}}(\mu \mathrm{M})$ & & & \\
Isoform 1 & $20 \pm 5$ & $20 \pm 3$ & $610 \pm 60$ \\
Isoform 2 & $30 \pm 5$ & & \\
Isoform 3 & $50 \pm 5$ & & \\
\hline \hline
\end{tabular}

contained in $\mathrm{ES}(<1 \%)$ and failed to show fluorescent bands when $10 \%$ native polyacrylamide gels were activity-stained with the 4-MU substrates. All three enzymes were glycosylated, as shown by their ability to bind to concanavalin A. The enzymes did not elute when the column was washed with $0.3 \mathrm{M}$ glucose, mannose or methylglucose, but were eluted by borate. $\beta$-Galactosidase did not bind to the affinity matrix $p$-aminobenzyl 1 -thio- $\beta$-D-galactopyranoside-agarose.

All enzymes had acidic $\mathrm{pH}$ optima between $4 \cdot 5-5 \cdot 0$ with an optimum between $4 \cdot 5-4 \cdot 8$ for $\beta$-glucosidase. $\beta$-N-acetylhexosaminidase used both 4-methylumbelliferyl $\mathrm{N}$-acetyl- $\beta$-D-glucosaminide and 4methylumbelliferyl $\mathrm{N}$-acetyl- $\beta$-D-galactosaminide as substrates. Gel filtration of ES on a column of Sephacryl S-300 HR, followed by assay of the fractions eluted with both substrates, showed an identical pattern of enzyme activity when each fraction was assayed with the 2 substrates. The apparent $\mathrm{K}_{\mathrm{m}}$ values were determined for the enzymes using 4methylumbelliferyl glycosides as substrates. Both $\beta$-N acetylhexosaminidase and $\beta$-galactosidase had apparent $\mathrm{K}_{\mathrm{m}}$ values for their respective substrates in the 20-50 $\mu \mathrm{M}$ range (Table 2) and the $\mathrm{K}_{\mathrm{m}}$ values showed variation depending on the isoform. However, 4-methylumbelliferyl $\beta$-D-glucoside was a relatively poor substrate for $\beta$-glucosidase, with an apparent $\mathrm{K}_{\mathrm{m}}$ value of $610 \mu \mathrm{M}$.

All three enzymes had a temperature optimum of approx. $50{ }^{\circ} \mathrm{C}$. $\beta$-Glucosidase was the most thermostable, retaining $95 \%$ of its activity after $10 \mathrm{~min}$ at $50{ }^{\circ} \mathrm{C}$, compared to $35 \%$ and $60 \%$ for $\beta$-N-acetylhexosaminidase and $\beta$-galactosidase, respectively. The activity of the three enzymes was unaffected by the addition of $\beta$-mercaptoethanol, suggesting that they did not contain disulphide bonds essential to the retention of activity. EDTA at concentrations up to $10 \mathrm{~mm}$ did not affect the activity, indicating that the enzymes were not metal ion-dependent. The activity
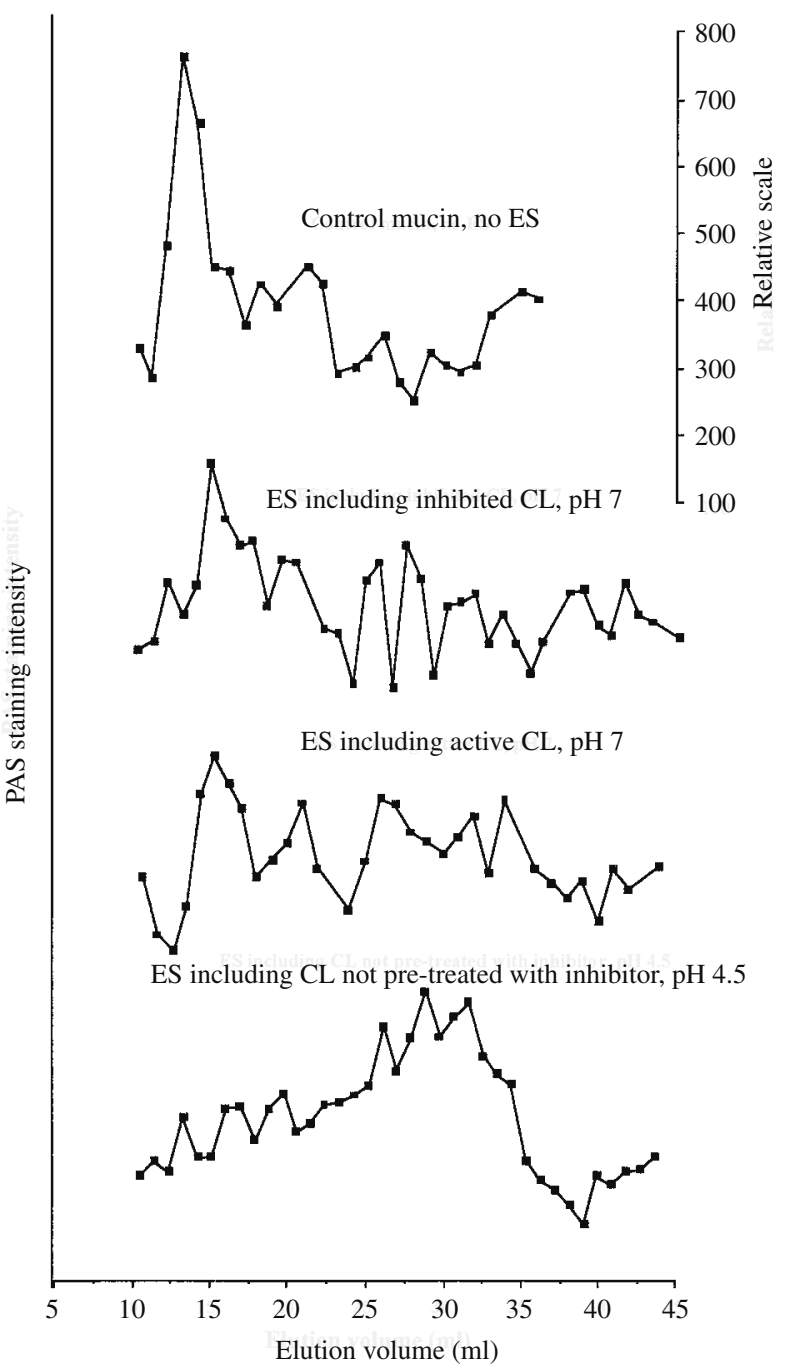

Fig. 2. Mucin degradation by Fasciola hepatica ES. Ovine small intestinal mucin was incubated with $50 \mu \mathrm{l}$ of ES as described in Materials and Methods. Fractions $(1 \mathrm{ml})$ were collected and $50 \mu \mathrm{l}$ aliquots were slot blotted and stained for carbohydrate using PAS stain. CL is an abbreviation for cathepsin L. A shift in the elution profile to the right is indicative of increased mucin degradation. 


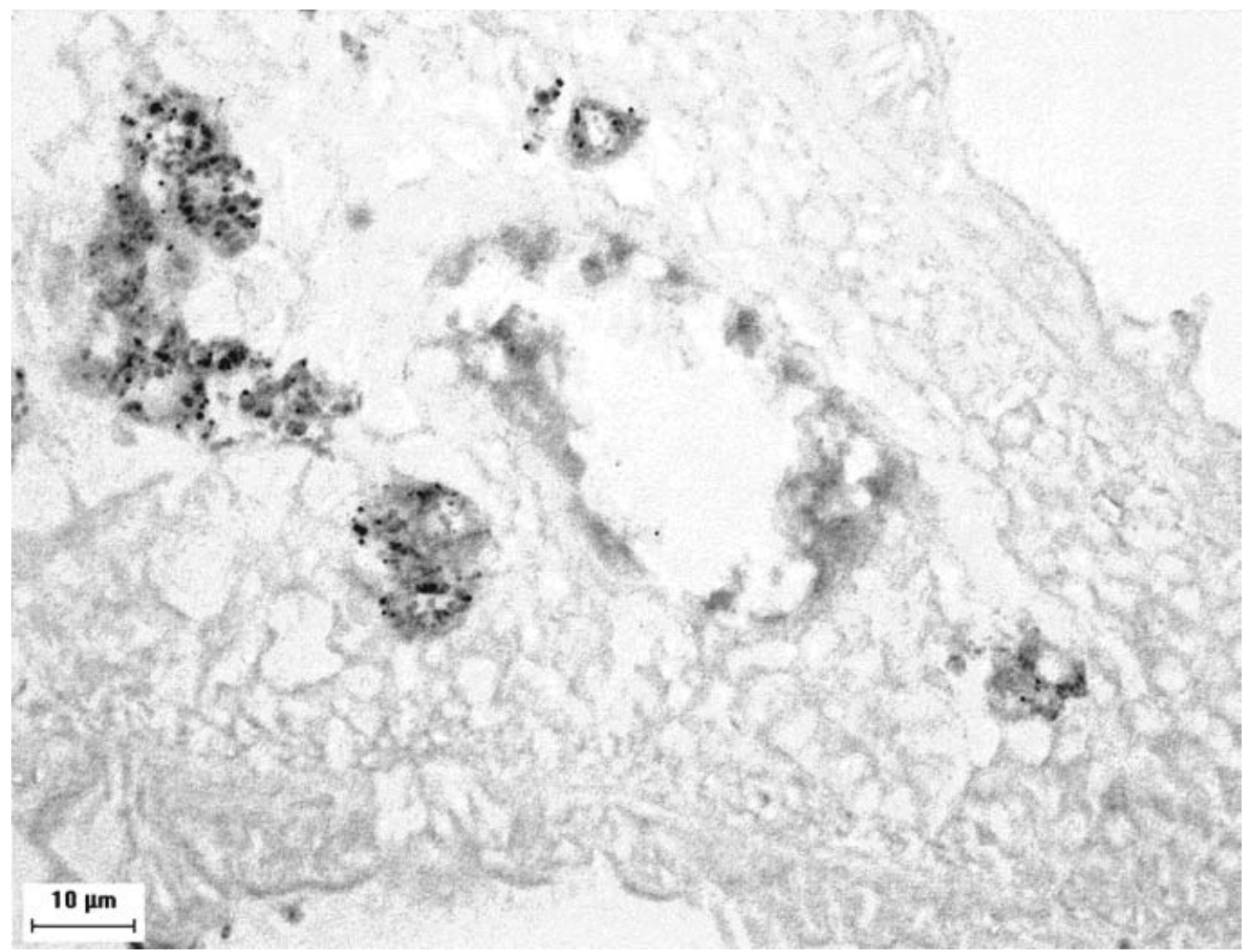

Fig. 3. Activity staining of Fasciola hepatica longitudinal section for $\beta$-N-acetylhexosaminidase activity using X-GlcNac.

of all 3 enzymes was stable in serum-free medium for 12 months at $-20{ }^{\circ} \mathrm{C}$.

\section{Mucin degradation}

F. hepatica ES was incubated with ovine intestinal mucin under a range of different conditions (Fig. 2). The extent of degradation was estimated by gel filtration of samples of mucin $(400 \mu \mathrm{g})$ which had been digested with ES for $24 \mathrm{~h}$ at $37^{\circ} \mathrm{C}$. An increase in PAS staining in lower molecular weight fractions (elution volume $20-40 \mathrm{ml}$ ) relative to the total staining and a shift of peaks to the right was interpreted as increased degradation. The most extensive degradation was observed with a sample that had been digested with ES (which had not been pre-treated with the cysteine protease inhibitor, Z-Phe-Ala-diazomethylketone to inactivate cathepsin L) in citrate buffer, $\mathrm{pH} 4 \cdot 5$. This was followed by samples digested at $\mathrm{pH} 7 \cdot 0$ with ES containing cathepsin L that was not inhibitor-treated, and ES in which the cathepsin $\mathrm{L}$ was inhibitor-treated at $\mathrm{pH} 4 \cdot 5$. Incubation of mucin with purified recombinant cathepsin $\mathrm{L} 1$ alone at $\mathrm{pH} 7 \cdot 0$ led to little, if any, degradation and the elution profile was essentially identical to that of the control sample in Fig. 2. F. hepatica cathepsin $\mathrm{L}$ has a broad $\mathrm{pH}$ activity profile ( $\mathrm{pH} 5-9)$ and is relatively stable at $37{ }^{\circ} \mathrm{C}$ and neutral $\mathrm{pH}$, unlike the mammalian enzyme (Dowd et al. 2000), so if cathepsin L were largely responsible for mucin degradation, a significant shift in the degradation pattern to the right would have been observed when mucin was incubated with this enzyme at $\mathrm{pH} 7 \cdot 0$. These results suggest that the presence of glycosidase activity (which is optimized at $\mathrm{pH} 4.5$ ) is essential to ensure degradation of the intestinal mucin. F. hepatica ES also degraded mucin from species not normally parasitized by this organism. A sample of chicken colonic mucin underwent extensive degradation when incubated with $F$. hepatica $\mathrm{ES}$ at $\mathrm{pH} 7 \cdot 0$ (data not shown).

\section{Activity staining for glycosidase activity}

Faint green-blue staining for $\beta$-galactosidase and $\beta$ $\mathrm{N}$-acetylhexosaminidase was observed surrounding the gut cavity after $20 \mathrm{~h}$ incubation with the X-Gal or X-GlcNac substrates. Fig. 3 shows staining for $\beta$ $\mathrm{N}$-acetylhexosaminidase ( $\beta$-galactosidase was similar, but fainter). This is in line with the findings of Moore \& Halton (1976) who observed a decrease in $\beta$-N-acetylhexosaminidase in adults compared to immature flukes. Small fragments of host tissue associated with the tegument also stained strongly positive for these enzymes, acting as a positive control. No $\beta$-glucosidase activity was present in any part of the fluke. 
DISCUSSION

We have documented for the first time the presence of glycosidase activity in the excretory-secretory products of $F$. hepatica. Assays using 4-methylumbelliferyl glycosides have shown that this class of hydrolytic enzymes is present and that the most abundant are $\beta$-galactosidase, $\beta$-N-acetylhexosaminidase and $\beta$-glucosidase. Glucose is not a common component of mucin glycoproteins, so it is unlikely that the relatively high abundance of $\beta$ glucosidase reflects an important role in mucin degradation. It may instead be important for nutrition, hydrolysing hepatocyte glycans, or may play a role in detoxification of host-derived xenobiotic glycosides, as does the human liver cytosolic $\beta$-glucosidase (Berrin et al. 2002). Human liver contains a specialised $\beta$-glycosidase that is important in degrading bile acids (Matern et al. 1997).

Mucin glycans contain galactose, N-acetylglucosamine and $\mathrm{N}$-acetylgalactosamine, which is $O$ linked to the peptide backbone of mucins. The presence of enzymes that hydrolyse these sugars is thus consistent with their hypothetical role in mucin degradation. Intestinal mucin glycans are often capped with $\alpha-1,2$ linked fucose and also sialic acid. The presence of $\alpha$-L-fucosidase and neuraminidase would also assist $F$. hepatica to degrade mucin glycans, as well as degrading red cell membrane glycans, which are rich in these sugars. The bile duct of the ruminant host is a mucus-rich environment, so that secretion of these enzymes would enable the parasite to penetrate the mucus layer to reach the epithelial surface.

The presence of $\alpha$-mannosidase and $\alpha$-linked galactosidase is less likely to be explained by a putative role in mucin degradation, since these structures are not abundant in mucins. Mannosidase may act on $\mathrm{N}$-glycans and the $\alpha$-galactosidase may act on blood group B structures, or Galili antigens (nonhuman $\alpha$-Gal structures). There has been little characterization of $F$. hepatica glycoproteins but the tegument is known to contain sialyl-Tn glycans (Freire et al. 2003) and a glycosylated 26-28 kDa diagnostic coproantigen (Abdel-Rahman, O’Reilly \& Malone, 1999). Newly-excysted juveniles (NEJs) are the life-cycle stage of $F$. hepatica that is ingested by the host. These then excyst in the gut and penetrate the intestinal wall. Since the gut wall is protected by mucin, it is likely that this immature stage will also secrete mucin-degrading enzymes and may secrete a range of the glycosidases consistent with host penetration and mucin degradation in the small intestine. This mixture of glycosidases may be different to those expressed by adult flukes and will be the subject of further studies.

It is unclear from the current data whether the presence of different isoforms reflect differently glycosylated forms of the same gene product, or different gene products. A search of the GenBank database (www.ncbi.nlm.nih.gov) for glycosidase genes in the related trematode species, Schistosoma japonicum, revealed the presence of a gene similar to the human hexosaminidase B preproprotein (BU797209, also accession number AY222924.1), a sequence with homology to the human $\beta$-galactosidase protective protein (BU716503), a sequence similar to human $\beta$-galactosidase 2 (AY223316.1) and a translated protein sequence similar to $\alpha$-L-fucosidase (Accession number AY222884.1). A BLAST search using a Caenorhabditis elegans $\beta$-galactosidase sequence as query also revealed another sequence from the $S$. japonicum EST database (BU791813) that had significant homology to both a $C$. elegans $\beta$-galactosidase and a similar enzyme in the mouse. A search of the TIGR database (www.tigr.org) provided one putative partial $\beta$-glucosidase sequence from a $S$.japonicum EST but revealed little else.

A pilot EST sequencing project for $F$. hepatica is underway at present (www.sanger.ac.uk/Projects/ S_mansoni/). When sequences for $F$. hepatica glycosidases become available, it will be possible to clone and overexpress these enzymes. This will facilitate their full purification and a more detailed survey of their properties, with particular reference to their specificity for naturally occurring glycans. The determination of the enzymes' specificity for physiological, rather than synthetic, substrates will provide a more comprehensive guide to the true function of the $F$. hepatica glycosidases.

This work was partly funded by the President's Research Award, University College Dublin. We are grateful to Margot Coady for technical assistance with histology.

\section{REFERENCES}

ABDel-RAhman, s., O'Reilly, K. L. \& MALOne, J. B. (1999). Biochemical characterization and localization of Fasciola hepatica 26-28 kDa diagnostic coproantigen. Parasite Immunology 21, 279-286.

Berrin, J. G., Mclauchlan, W. R., NeEds, P., Williamson, G., PUigserver, A., KroOn, P. A. \& JUGE, N. (2002).

Functional expression of human liver cytosolic beta-glucosidase in Pichia pastoris. Insights into its role in the metabolism of dietary glucosides. European Fournal of Biochemistry 269, 249-258.

BRADFORD, M. M. (1976). A rapid and sensitive method for the quantitation of microgram quantities of protein utilizing the principle of protein-dye binding. Analytical Biochemistry 72, 248-254.

CARMONA, C., DOWD, A. J., SMith, A. M. \& DALTON, J. P. (1993). Cathepsin L proteinase secreted by Fasciola hepatica in vitro prevents antibody-mediated eosinophil attachment to newly excysted juveniles. Molecular and Biochemical Parasitology 62, 9-17.

COLlins, P. R., STACK, C. N., O’NEILl, S. M., DOYLE, S., RYAN, T., BRENNAN, G. P., MOUSLEy, A., STEWART, M., MAule, A. G., DAlton, J. P. \& DONnElly, s. (2004). Cathepsin L1, the major protease involved in liver 
fluke (Fasciola hepatica) virulence: propeptide cleavage sites and autoactivation of the zymogen secreted from gastrodermal cells. Fournal of Biological Chemistry 279, 17038-17046.

CORFIELD, A. P. \& MYERSCOUGH, N. (2000). Glycosidase activity. Methods in Molecular Biology 125, 403-416.

DAlTON, J. P., McGONigle, S., ROLPH, T. P. \& ANDREWS, S. J. (1996). Induction of protective immunity in cattle against infection with Fasciola hepatica by vaccination with cathepsin L proteinases and with hemoglobin. Infection and Immunity 64, 5066-5074.

DAVIES, J. R. \& CARLSTEDT, I. (2000). Isolation of large gel-forming mucins. Methods in Molecular Biology $125,3-13$.

DOWD, A. J., DOOLEY, M., O'FÁGÁIN, C. \& DALTON, J. P. (2000). Stability studies on the cathepsin L proteinase of the helminth parasite, Fasciola hepatica. Enzyme and Microbial Technology 27, 599-604.

EVERSON PEARse, A. G. (1972). Histochemistry, Theoretical and Applied, vol. 2, 3rd Edn, pp. 1324-1325. Churchill Livingstone, Edinburgh and London.

Freire, T., CASARAVIlla, C., CARMona, C. \& Osinaga, E. (2003). Mucin-type O-glycosylation in Fasciola hepatica: characterisation of carcinoma-associated Tn and sialyl-Tn antigens and evaluation of UDP-GalNAc : polypeptide N-acetylgalactosaminyltransferase activity. International fournal for Parasitology 33, 47-56.

FUJINO, T. \& ISHII, Y. (1986). Comparative histochemical studies of glycosidase activity in some helminths. Fournal of Helminthology 60, 1-13.

JefFERIES, J. R., CAMPBEll, A. M., VAN ROSSUM, A. J., BARRETT, J. \& BROPHY, P. M. (2001). Proteomic analysis of Fasciola hepatica excretory-secretory products.

Proteomics 1, 1128-1132.

LAEMMLI, U. K. (1970). Cleavage of structural proteins during the assembly of the head of bacteriophage T4. Nature, London 227, 680-685.
LOJDA, z. (1970). Indigogenic methods for glycosidases. II. An improved method for beta-D-galactosidase and its application to localization studies of the enzymes in the intestine and in other tissues. Histochemie 23, 266-288.

MAS-COMA, S., BARGUES, M. D. \& ESTEBAN, J. G. (1999). Human fasciolasis. In Fasciolosis (ed. Dalton, J. P.), pp. 411-434. CAB International, Wallingford, UK. MATERn, H., HEINEMANN, H., LEGLER, G. \& MATERN, S. (1997). Purification and characterization of a microsomal bile acid beta-glucosidase from human liver. Fournal of Biological Chemistry 272, 11261-11267.

MOORE, M. N. \& HALTON, D. w. (1976). Fasciola hepatica: histochemical observations on juveniles and adults and the cytopathological changes induced in infected mouse liver. Experimental Parasitology 40, 212-224.

MULCAHY, G., O'CONNOR, F., McGONIGLE, S., DOWD, A., CLERY, D. G., ANDREWS, S. J. \& DALTON, J. P. (1998). Correlation of specific antibody titre and avidity with protection in cattle immunized against Fasciola hepatica. Vaccine 16, 932-939.

o’NEILL, S. M., MiLls, K. H. \& DALTON, J. P. (2001). Fasciola hepatica cathepsin L cysteine proteinase suppresses Bordetella pertussis-specific interferon-gamma production in vivo. Parasite Immunology 23, 541-547.

SMITH, A. M., DOWD, A. J., HEFFERNAN, M., ROBERTSON, C. D. \& DALTon, J.P. (1993). Fasciola hepatica: a secreted cathepsin L-like proteinase cleaves host immunoglobulin. International Yournal for Parasitology 23, 977-983.

THORNTON, D. J., HOLMES, D. F., SHEEHAN, J. K. \& CARLSTEDT, I. (1989). Quantitation of mucus glycoproteins blotted onto nitrocellulose membranes. Analytical Biochemistry 182, 160-164.

WILKINSON, G. N. (1961). Statistical estimations in enzyme kinetics. Biochemical Fournal 80, 324-332. 